\title{
ENDECASÍLABOS Y DECASÍLABOS CON ACENTO REGULAR EN QUINTA SÍLABA Y OTROS EXPERIMENTOS RÍTMICOS DEL POETA MEXICANO RUBÉN BONIFAZ NUÑO
}

\section{HENDECASYLLABIC AND DECASYLLABIC VERSES REGULARLY STRESSED ON THE $5^{\text {TH }}$ SYLLABLE AND OTHER RYHTMICAL EXPERIMENTS IN THE MEXICAN POETRY OF RUBÉN BONIFAZ NUÑO}

\author{
JosÉ ENRIQUE MARTÍNEZ \\ Universidad de León
}

\begin{abstract}
Resumen: Tanto el endecasílabo galaico antiguo, con acentuación en quinta sílaba, como el decasílabo con tal acentuación han sido considerados de uso absolutamente excepcional. Sin embargo, las investigaciones rítmicas del poeta mexicano Rubén Bonifaz Nuño lo llevaron al uso de aquellos versos acentuados sistemáticamente en la mencionada quinta sílaba, combinándolos con otros versos de medidas cercanas (eneasílabos y octosílabos) en una misma estrofa y a lo largo de una composición, sin abandonar en otros casos el ritmo tradicional de los metros indicados. Puede afirmarse que Bonifaz Nuño ha convertido en habitual lo que siempre fue excepcional.
\end{abstract}

Palabras clave: Bonifaz Nuño, innovaciones métricas, endecasílabos con acentuación en quinta sílaba.

Abstract: Both the old Galician hendecasyllable, typically stressed on the 5th syllable, and the decasyllable with the same accent have been traditionally considered utterly exceptional. 
Nevertheless, the rhythmical experimentation carried out by the Mexican poet Rubén Bonifaz Nuño resulted in the use of this Galician hendecasyllable, systematically stressed on the 5th syllable and combined with similar verses (mainly octosyllabic and eneasyllabic) both in the same stanza and throughout the entire compositions, even though the traditional meter for this type of line was never entirely abandoned. Hence, it can be asserted that Bonifaz Nuño has turned into usual that which had always been exceptional.

Key words: Bonifaz Nuño, metrical innovation, hendecasyllable stressed on the 5th syllable. 


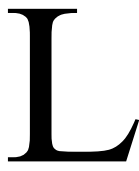

as posibilidades rítmicas del endecasílabo han propiciado numerosos y variados análisis que lo han convertido en el verso más y mejor estudiado de nuestra tradición métrica. La posición regular de las sílabas acentuadas ha hecho distinguir distintos tipos de endecasílabo reducibles a dos principales: endecasílabo a maiori o heroico, con acento regular en sexta sílaba (además de la décima) y endecasílabo a minori o sáfico, que acentúa de modo regular las sílabas cuarta y octava. El endecasílabo dactílico o de gaita gallega, con acentos en cuarta y séptima sílabas, prescinde del carácter yámbico de los demás metros endecasilábicos; sobre él versa una monografía de Domínguez Caparrós ${ }^{1}$. En todos los casos pueden llevar otros acentos secundarios que pueden servir para establecer diferentes tipos de endecasílabo que no son más que manifestaciones del carácter polirrítmico de dicho verso.

Entre la rica variedad rítmica del endecasílabo quizá el de menor uso en nuestra tradición lírica sea el llamado «galaico antiguo», con acento constitutivo regular en quinta sílaba. Los primeros tratados de métrica no lo contemplaban y los actuales se refieren a su excepcionalidad. Caramuel, por poner un ejemplo, al hablar de «aquellos versos que tienen el último acento en la décima sílaba» (que él llama decasílabos o decámetros) establece hasta once tipos acentuales, en ninguno de los cuales se prevé la acentuación en quinta, en séptima o en novena sílabas, comentando: «Aquí se ve claro que la séptima y novena sílabas apenas consienten el acento para no dañar el encanto y la armonía» ${ }^{2}$. Sin duda, lo mismo pensaría y habría podido afirmar

${ }^{1}$ Domínguez CAPARrós, José: El moderno endecasílabo dactílico, anapéstico o de gaita gallega. Sevilla: Rhythmica, Revista Española de Métrica Comparada. Anejo III, 2009.

${ }^{2}$ Caramuel, Juan: Primer Cálamo. Tomo II: Rítmica. Valladolid: Universidad de Valladolid, 2007, p. 109. 
de la acentuación en quinta sílaba. En los tratados modernos este tipo de acentuación primordial en la quinta sílaba del endecasílabo se considera tan poco canónica como ajena al modo de ser de dicho metro. Henríquez Ureña, tras señalar que el endecasílabo con acento en quinta sílaba lo conocía la poesía galaicoportuguesa desde el siglo XIII, aporta como casos excepcionales la «Balada laudatoria» a Valle-Inclán, de Rubén Darío, y la composición «El gran doctor» de González de Prada ${ }^{3}$. «Apenas se pueden citar otros ejemplos», señala Domínguez Caparrós ${ }^{4}$. Sólo la «Balada en loor de Valle-Inclán» cita Navarro Tomás ${ }^{5}$, lo mismo que $\mathrm{Baehr}^{6}$, señalando ambos que es un tipo de endecasílabo formado por la agrupación de un hexasílabo y un pentasílabo polirrítmicos.

No es de nuestro interés la presencia esporádica de ese tipo de endecasílabo con acento en quinta sílaba, en poemas de composición libre o de otro tipo ${ }^{7}$, sino su manifestación autónoma a lo largo de una composición; ni, por supuesto, es objeto de este trabajo la presencia de tal acentuación como apoyo extrarrítmico de otros tipos de endecasílabos, sino como acento constituyente y sustentación rítmica y regular de tal metro a lo largo de una o varias composiciones, en las cuales puede combinarse con otros metros igualmente acentuados en quinta sílaba. Este tipo de acentuación del endecasílabo resulta extraña a nuestra tradición, tal vez porque contradice el carácter esencialmente yámbico de dicho verso y acaso porque los endecasílabos con acento en

${ }^{3}$ Henríquez Ureña, Pedro: Estudios de versificación española. Buenos Aires: Universidad de Buenos Aires, 1961, p. 344.

${ }^{4}$ Domínguez Caparrós, José: Diccionario de métrica española. Madrid: Alianza Editorial, 1999 , p. 140.

${ }^{5}$ Navarro Tomás, Tomás: Métrica española. Reseña histórica y descriptiva. Cuarta edición (primera edición: 1956). Madrid-Barcelona: Guadarrama, 1974, p. 512.

${ }^{6}$ BAEHR, Rudolf: Manual de versificación española. Madrid: Gredos, 1970, p. 142.

${ }^{7}$ Esporádicamente aparecen endecasílabos acentuados en $5^{\mathrm{a}}$ sílaba en los Sonetos a la Virgen (1937) del poeta mexicano Octavio G. Barreda, como él mismo recordó en un artículo titulado «Mis Sonetos a la Virgen», publicado en el diario Hoy el 30 de abril de 1937; puede leerse el artículo de Barreda en SCHNEIDER, Luis Mario: «A propósito de las obras de Barreda y la edición de Lourdes Franco», en Literatura Mexicana, vol. I. México: UNAM, 1990, pp. 456-457. Habla Barreda de «esos imprevistos acentos en la quinta sílaba de los endecasílabos y dar de esta manera una musicalidad extraña, un lenguaje indispensable a la idea, un nuevo aliento a esos versos ya de por sí gastados y roídos». 
quinta sílaba «cobran naturaleza hemistiquial dodecasilábica»» ${ }^{8}$.

En cuanto al decasílabo, la tradición métrica distingue el decasílabo compuesto y el simple. El primero se compone de dos hemistiquios que funcionan como la suma de dos pentasílabos, con acentos, por lo tanto, en cuarta y novena sílabas, con sus variantes dactílica (acentos en primera y cuarta de cada hemistiquio), yámbica (acentos en segunda y cuarta) y polirrítmica (combina los tipos dactílico y yámbico). El decasílabo simple presenta tres variedades: el arcaico, que sitúa los acentos siempre en sílabas impares y que «se da raras veces»", el decasílabo anapéstico o de himno, con acentos rítmicos en las sílabas tercera, sexta y novena, que es «la variante más habitual del decasílabo» ${ }^{10}$, y el tipo mixto, también de escaso uso, con acentos en las sílabas segunda, sexta y novena.

Con uno y otro metro, el del endecasílabo y el del decasílabo, ha experimentado el poeta mexicano Rubén Bonifaz Nuño, acentuando sistemáticamente, con regularidad y como principio rítmico esencial, la quinta sílaba y variando la posición de los demás acentos interiores, en composiciones de versos de medida uniforme o mezclando distintas medidas. La muerte del gran poeta a principios de 2013, concretamente el 31 de enero, me ha incitado a estudiar las innovaciones rítmicas por él practicadas y que afectan al endecasílabo, al decasílabo y a otros metros con ellos combinados. Tales innovaciones las había sorprendido años antes, cuando cayó en mis manos Luz que regresa (2007) ${ }^{11}$, una antología de su obra lírica, cuyo conocimiento completo ahora con De otro modo lo mismo ${ }^{12}$, que en 1979 recogía «casi completas» las obras en verso del mexicano, de La muerte del ángel (1945) a La flama en el espejo (1971), nueve libros en total, a los que ha sumado otros poemarios reunidos con el mismo título, De otro modo lo mismo (1996) y Versos (1996), recopilaciones a las que siguió Calacas (2003), el último poemario del

\footnotetext{
${ }^{8}$ Varela Merino, Elena; Moíno Sánchez, Pablo y Jauralde Pou, Pablo: Manual de métrica española. Madrid: Castalia, 2005, p. 198.

${ }^{9}$ BAEHR, Rudolf: Manual de versificación española, cit., p. 128.

${ }^{10}$ Ibid.

${ }^{11}$ Bonifaz Nuño, Rubén: Luz que regresa. Antología. Madrid: Visor, 2007.

${ }^{12}$ Bonifaz Nuño, Rubén: De otro modo lo mismo. México: Fondo de Cultura Económica, 1976.
} 
escritor. Cuando escribo estas líneas se anuncia la publicación de su Poesía completa para presentarla en la feria del libro de Guadalajara (México) de 2013. Dado que ni el autor ni su obra son adecuadamente conocidos en España, conviene aportar algunos datos previos.

Como ya se ha señalado, Rubén Bonifaz Nuño murió el último día del año 2013. Había nacido en Córdoba (Veracruz) en 1923, pero su vida transcurriría en Ciudad de México. Fue, ante todo, un humanista, destacando como traductor de autores clásicos y como poeta. En aquel campo vertió al español la Eneida (1973) de Virgilio, Arte de amar. Remedios de amor (1975) de Ovidio, De la natura de las cosas (1984) de Lucrecio, Olímpicas (1990) de Píndaro, Hipólito (1998) de Eurípides y la Ilíada (2008) de Homero. Al mismo campo de intereses responden sus dos ensayos: El amor y la cólera: Cayo Valerio Catulo (1977) y Los reinos de Cintia. Sobre Propercio (1978). Como poeta es autor de obra abundante, con dieciocho títulos, entre los que merecen ser destacados Los demonios y los días (1956), El manto y la corona (1958), Fuego de pobres (1961), Siete de espadas (1966), La flama en el espejo (1971) y As de oros (1981).

La poesía de Bonifaz Nuño significa la vuelta «a un clasicismo que se centra en el diálogo entre la tradición clásica, el mundo prehispánico y los inicios de la corriente coloquialista, a lo que hay que sumar la impronta que deja en la poesía de compromiso social» ${ }^{13}$. El mayor estudioso de la poesía de Bonifaz Nuño, Sandro Cohen, la ha caracterizado formal y temáticamen$\mathrm{te}^{14}$. Formalmente, el «dominio absoluto de los variadísimos ritmos y cadencias de la versificación castellana» facilita el empeño del poeta en «innovar el verso desde dentro, de manera sutil [...], a partir de sus acentos, o apoyos principales»; temáticamente incide en «el amor y la relación del ser humano con Dios y la sociedad que lo rodea»; afinando más, Cohen funde los dos temas en uno: «El hombre que busca sentido a la vida por medio

${ }^{13}$ Esteban, Ángel y Gallego Cuiñas, Ana: «Panorámica de la poesía hispanoamericana de las generaciones de la mitad del siglo XX»), en Juegos de manos (Antología de la poesía hispanoamericana de mitad del siglo XX). Madrid: Visor, 2008, p. 125.

${ }^{14}$ La caracterización de la poesía de Bonifaz Nuño y las citas entrecomilladas proceden de CoHEn, Sandro: «El universo poético de Rubén Bonifaz Nuño», en BonIfaZ NuÑo, Rubén: Luz que regresa. Antología, cit., pp. 7-21. 
de sus pasiones y su necesidad de trascender». Esa «búsqueda amorosa» va impregnada de «elementos místicos -en el sentido cristiano y en el cabalístico-, profanos, populares, herméticos eróticos, simbólicos e incluso mágicos, lo cual refleja fielmente las búsquedas intelectuales, espirituales y literarias» del poeta. La poesía de Bonifaz Nuño explora básicamente el fenómeno amoroso en sus distintas direcciones -el amor humano y el amor divino-, a través de símbolos y metáforas (indígenas, bíblicas, occidentales), alusivas a fuerzas contrarias que combaten primero para reconciliarse después, cifrando en esta reconciliación de contrarios la redención, la resurrección, o reencarnación, que es una fuerza tan poderosa en la obra del mexicano que «está presente prácticamente desde el principio y llega hasta sus últimos libros». Lo señalado, siguiendo a Cohen, incide en el hecho de que se trata de una poesía compleja, en cuyo fondo se conjugan distintas corrientes: la cábala, la alquimia, la magia, las ciencias ocultas, el mundo indígena, la tradición bíblica y la clásica.

\section{Sonetos y otras formas canónicas}

El primer texto lírico de Bonifaz Nuño, La muerte del ángel (1945), es un poemario de diez sonetos que se ajustan al orden tradicional del endecasílabo y del soneto. En el segundo libro, Imágenes (1953), en el que se centra este estudio, pues con él inicia sus investigaciones rítmicas, podemos apreciar ya la mixtura de formas canónicas, tradicionales, con novedosos experimentos rítmicos sobre la base de lo heredado. Bonifaz Nuño compone muchos de los poemas de tal libro en sonetos (treinta y cinco en total) respetuosos aparentemente con la forma clásica. Los sonetos se agrupan en secciones diferentes: «Retratos de mujer» son ocho sonetos; el poema 23 -el poeta gusta más de numerar que de titular sus poemas- se compone de tres excelentes sonetos, etc. Tres de estas series requieren algún comentario: «Retratos de mujeres», «Estudios» y «Canto del afán amoroso». «Retratos de mujeres» incluye dos sonetos a Eurídice entre los que se intercala una composición en tercetos de versos endecasílabos y decasílabos blancos con acento en quinta sílaba, contrastando con la regularidad canónica, silábica y acentual, de los 
sonetos. En la sección «Estudios», que acoge la traducción de una oda de Horacio, una composición en liras y una indispensable «Poética» que analizaremos más adelante, aparecen también los «Sonetos a la Sulamita», cinco en total; tres de ellos siguen el modelo clásico, pero con algunas particularidades que son índice del afán de búsqueda de una nueva música sin salirse del esquema tradicional. En el soneto I todos los endecasílabos son sáficos, acentuados, por lo tanto, en cuarta y octava sílabas, pero además acentúan también la primera de modo regular, admitiendo pausa entre la quinta y la sexta sílabas, permaneciendo como átonas las demás sílabas, «normas estilísticas» a las que, según los tratadistas, se somete este tipo de verso ${ }^{15}$ :

Sola en el seno de la sombra muda dices mi nombre, y en tu sueño triste vagas en busca del amor que hubiste.

Tú, con el vuelo de tu voz desnuda. (p. 65) ${ }^{16}$

El soneto II acentúa de modo regular únicamente la cuarta sílaba, con la característica de que antes de ella puede haber acentos ocasionales, pero ninguno entre la cuarta y la decima. De «endecasílabo primario» lo tildó Dorothy C. Clarke; para algunos, señala Domínguez Caparrós, deriva del endecasílabo a minori y del de gaita gallega; para otros es un verso defectuoso ${ }^{17}$. La novedad que aporta Bonifaz Nuño es que no intercala algún endecasílabo suelto entre otros a minori o a maiori sino que es el verso de toda la composición lo cual no deja de ser un reto, aunque en la lectura resulte un ritmo acaso monótono y desmayado, como puede comprobarse en el primer cuarteto:

Y fue la llama de tu acercamiento

-rosa de místicas resurrecciones-

el poderío de los escuadrones

en los despojos de mi vencimiento. (p. 65)

\footnotetext{
${ }^{15}$ Domínguez Caparrós, José: Diccionario de métrica española, cit., p. 143.

${ }^{16}$ Las citas de los diferentes poemas proceden de BonIFAZ NuÑo, Rubén: De otro modo lo mismo, cit.; se añade, en cada caso, la página.

${ }^{17}$ Domínguez Caparrós, José: Diccionario de métrica española, cit., p. 142.
} 
El soneto III adopta el modelo del endecasílabo galaico antiguo, acentuando regularmente los versos en quinta sílaba -tal vez la nota más llamativa y atractiva de las innovaciones rítmicas del poeta mexicano, que sólo excepcionalmente se aprecia en sus sonetos-. El primer cuarteto dice así:
A solas, oscuro, sin ti, vacío, en la vasta noche, sin ti, desierta, buscándote llego junto a tu puerta, húmedas mis sienes con el rocío. (p. 66)

Finalmente, el soneto $\mathrm{V}$ está compuesto en endecasílabos de gaita gallega, con acentos en primera, cuarta y séptima sílabas, que «desde el punto de vista clasicista, se lo considera falto de la gravedad del endecasílabo, por estar cerca del sonido vulgar de la gaita gallega» ${ }^{18}$. Leemos el segundo cuarteto:

\section{Cante mi amor y su canto te siga, busque en tu oído nostálgicos lechos mientras del aire los lazos deshechos mecen el claro rumor de la espiga. (p. 67)}

Bonifaz Nuño acepta, por lo tanto, el esquema del soneto e investiga diversos ritmos que suenen con otra música al oído habituado a la fluencia de los endecasílabos italianos. Por otro lado, la poesía del mexicano es, a la vez, una muestra de las posibilidades expresivas de diferente cuño del metro clásico.

«Canto del afán amoroso», que cierra el poemario, se compone de veinticinco partes o poemas que alternan la silva libre (13 composiciones) y los sonetos (12), en este caso canónicos. La silva va sumando versos blancos o sueltos de distintas medidas, aunque son los endecasílabos, heroicos o sáficos, los predominantes. Cobra interés el hecho de que cierre la serie de silvas y el largo poema, por lo tanto, con un verso de rima consonante, como si ofreciera un asiento sonoro al poema en su totalidad, a lo que hay que añadir la aliteración de los sonidos st (triste, tristemente, fuiste, misterio, abriste):

${ }^{18}$ Ibid., p. 139. 
Qué felizmente triste

fuiste; qué tristemente

alumbraste el misterio de su vida.

Ella estuvo contigo, corazón;

vino, y llamó a tus puertas,

como a las de su casa, y tú le abriste. (p. 99)

Otras formas clásicas usa el poeta en su libro Imágenes, como la lira garcilasiana en el poema «Liras (15 estrofas) ${ }^{19}$, la décima octosilábica en las «Canciones para velar un sueño», la primera de las cuales es sólo media décima (una quintilla), mientras la última termina con un tetrasílabo, y los poemas en eneasílabos libres ( 8 en total), es decir, sin regularidad acentual. Pero este trabajo va enfocado básica y principalmente al examen de las novedades introducidas por el poeta mexicano, que se añaden a las analizadas hasta este momento.

\section{Innovaciones métricas anteriores a Imágenes: "El caracol»}

Entre el libro de 1945, La muerte del ángel, y el de 1953, Imágenes, verdadero muestrario de diferentes y novedosos esquemas rítmicos, Bonifaz Nuño escribió Algunos poemas no coleccionados (1945-1952), que, como el título indica, no fueron incluidos en los libros correspondientes a esas fechas; entre ellos hay sonetos clásicos, una silva libre impar que combina versos blancos de once, siete y cinco sílabas, y un poema final, en cinco partes, titulado «El caracol», fechado en 1952, en el que es patente la decantación del poeta hacia la innovación rítmica que será marca de poemas y libros posteriores. En «El caracol» todos los versos - exceptuando cuatro de ellos, pentasílabos, en una adaptación de la estrofa sáfica, como más adelante observaremos- se regulan rítmicamente acentuando la quinta sílaba, con variabilidad acentual en las demás sílabas, sean endecasílabos -la mayoría-, decasílabos, eneasílabos o incluso octosílabos. El acento constituyente en quinta sílaba es la norma rítmica del poema, que, ajeno a las combinaciones tradicionales de diferentes metros, se regula únicamente sobre dicha sílaba tónica,

${ }^{19}$ En la primera lira, el segundo verso es dodecasílabo: «Casi del amor, instante que me diste». No he podido comprobar si se trata o no de una errata (*«casi de amor, instante que me diste»). 
tendiendo, de todas formas, a la regularidad silábica sobre la base del endecasílabo como verso predominante.

«El caracol» nos ofrece, en sus cinco partes, algunas de las opciones métrico-rítmicas experimentadas después por el poeta en su libro Imágenes: a) La silva libre que combina versos de distinta medida (endecasílabos, decasílabos y eneasílabos principalmente) cuya marca rítmica es la acentuación regular en quinta sílaba en todos los casos; b) Estrofas de cuatro versos de arte mayor con acentuación en quinta sílaba que en este caso siguen un esquema silábico también regular: 11 - 11 - 10 - 11. Tal esquema varía en la parte tercera (estrofas sáficas, de análisis posterior) y en la quinta, que es un único cuarteto de 11 - 10 - 10 - 8 sílabas. Salvo los pentasílabos de las estrofas sáficas, todos los demás versos portan el acento constituyente en quinta sílaba, como manera de acostumbrar el oído a músicas poco habituales.

\section{Poética}

Imágenes divide su contenido en tres grandes apartados: «Imágenes», «Estudios» y «Poemas de amor». En la segunda parte aparece el poema «Poética», distribuido, a su vez, en cinco secciones que merece la pena analizar temática y métricamente, pues no sólo manifiesta el entendimiento que de la poesía mantenía el poeta en aquel momento, sino también la necesidad del ritmo adecuado en cada ocasión. Por otro lado, «Poética» acoge una interesantísima variedad rítmica.

La primera sección del poema parte de una imagen contraria a lo que es la poesía: el agua y el vaso que brillan juntos, pero sin fundirse la forma (el vaso) con el contenido (el agua); de modo opuesto, la esencia de la poesía es la fusión de forma y vida, palabra y pensamiento, que en la poesía son una y la misma cosa. Métricamente se trata de diez versos tetradecasílabos blancos divididos en dos quintetos. Los versos llevan acentos fijos en las sílabas $4^{\mathrm{a}}, 8^{\mathrm{a}}$ y $13^{\mathrm{a}}$, por lo que no se trata de versos alejandrinos, cuya característica es la ser versos compuestos de dos hemistiquios heptasilábicos. En el poema de Bonifaz Nuño los hemistiquios posibles son de $9+5$ o de $5+9$ sílabas: 
Próximos brillan el sonoro vaso y el agua, mas no se funden uno y otra. Siempre es distinta... (p. 70)

La segunda parte de la «Poética» propone variaciones rítmicas diferentes al endecasílabo tradicional:

No siempre en las alas del italiano verso cristalino vuele sonoro el endecasílabo. Otras veces un compás lo lleve tenue y sombrío. (p. 70)

A veces el poema, si expresa «algún sentimiento apagado, oscuro», requiere un compás «tenue y sombrío», «un movimiento sosegado», levedad y blandura, adecuación en suma. Y, en efecto, el poema vuela con un ritmo diferente al endecasílabo italiano en los cinco cuartetos de versos blancos de arte mayor, que siguen este esquema silábico regular: $11-11$ - 10 - 11, disponiendo también de regularidad acentual en $5^{\text {a }}$ sílaba, como se puede comprobar en la estrofa transcrita.

La sección tercera, que entiende la poesía como modo de eternizar el instante, de liberarse del tiempo y de la muerte («el canto perfecto, que presta / tiempo sin tiempo a la vida»), consta de cinco cuartetos de versos blancos, con la siguiente distribución silábica en cada estrofa: 9 - $11-10$ - 8. Frente a la sección anterior, en esta la acentuación no es uniforme: cada metro adopta una propia:

a) Los endecasílabos, de gaita gallega, acentúan en $1^{\mathrm{a}}, 4^{\mathrm{a}} \mathrm{y}$ $7^{\mathrm{a}}$ sílabas, con dos excepciones: «llegan las cosas; por la transparencia» $\left(1^{\mathrm{a}}, 4^{\mathrm{a}}\right)$ y «suben serenas hasta el pensamiento» $\left(1^{\mathrm{a}}, 4^{\mathrm{a}}, 6^{\mathrm{a}}\right)$.

b) Los decasílabos, de himno, acentúan en las sílabas $3^{\mathrm{a}}$ y $6^{\mathrm{a}}$.

c) Los eneasílabos, en $2^{\mathrm{a}}$ y $5^{\mathrm{a}}$.

d) Los octosílabos, en $1^{\mathrm{a}}$ y $4^{\mathrm{a}}$, acompasando su ritmo con los endecasílabos.

Se puede apreciar tal variedad y mixtura en la primera estrofa:

$\mathrm{Al}$ aire con luces delgadas

(eneasílabo: $2^{\mathrm{a}}, 5^{\mathrm{a}}, 8^{\mathrm{a}}$ ) dulce la aurora traspasa y enciende; (endecasílabo: $1^{\mathrm{a}}, 4^{\mathrm{a}}, 7^{\mathrm{a}}, 10^{\mathrm{a}}$ ) 
Según expresa el poeta en la sección cuarta de «Poética», no son los temas los que hacen la poesía, por lo que cualquier asunto puede ser poesía «si la llama de la vista lo enciende». La materia se dignifica y eleva, y aspira a eternizarse en la poesía cuando la palabra le da «lumbre, intensidad y sentido». Esta sección la componen otros cinco cuartetos de versos endecasilábicos que acentúan en $3^{\mathrm{a}}, 7^{\mathrm{a}}$ y $10^{\mathrm{a}}$ sílabas, con otros posibles acentos secundarios de posición variable:

\author{
Cualquier tema debe ser admitido \\ en la grávida pureza de un verso \\ como noble material. El asunto \\ no es la fuente de la dulce hermosura. (p. 72)
}

El ritmo adquiere cierta serena lentitud acaso apta para expresa poéticamente un pensamiento; el ritmo parece adecuado, por lo tanto, para la demorada reflexión poética.

La belleza, la poesía, es el único amparo en nuestra indigencia, señala la parte última de «Poética»:

Porque por ella en lo mudable asimos

la forma - esencia- de lo permanente,

lúcidamente contenida

por el ser profundo del poema. (p. 73)

Esos versos forman uno de los cinco cuartetos de la sección. Todas las estrofas tienen la misma estructura silábica y acentual: 11 - 11 - 9 - 10. Actualmente:

a) Los endecasílabos son heroicos o sáficos, y seis de los diez acentúan también en primera sílaba.

b) Los decasílabos -el verso final de cada estrofa- acentúan en $5^{\mathrm{a}}$ sílaba.

c) Los eneasílabos, llamados de canción, acentúan en $4^{\mathrm{a}}$ sílaba, a excepción del siguiente: «No importa que lo ignoren muchos» (podría regularizarse con los demás eneasílabos suponiendo un acento en que). 
Pueden extraerse algunas conclusiones tras el análisis métrico de «Poética»:

1. Salvo la parte primera, las otras cuatro se componen de cinco cuartetos, tomando «cuarteto» como denominación de «toda estrofa de cuatro versos largos, en especial si son endecasílabos $\rangle^{20}$.

2. Esta regularidad estrófica se corresponde con cierta regularidad silábica, por cuanto en cada sección los cuartetos guardan la misma proporcionalidad silábica. En la siguiente tabla se indica la estructura silábica y acentual de las estrofas de cada sección:

$$
\begin{array}{lllll}
\text { II } & 11\left(5^{\mathrm{a}}\right) & -11\left(5^{\mathrm{a}}\right) & -10\left(5^{\mathrm{a}}\right) & -11\left(5^{\mathrm{a}}\right) \\
\text { III } & 9\left(2^{\mathrm{a}}, 5^{\mathrm{a}}\right) & -11\left(1^{\mathrm{a}}, 4^{\mathrm{a}}, 7^{\mathrm{a}}\right) & -10\left(3^{\mathrm{a}}, 6^{\mathrm{a}}\right) & -8\left(1^{\mathrm{a}}, 4^{\mathrm{a}}\right) \\
\text { IV } & 11\left(3^{\mathrm{a}}, 7^{\mathrm{a}}\right) & -11\left(3^{\mathrm{a}}, 7^{\mathrm{a}}\right) & -11\left(3^{\mathrm{a}}, 7^{\mathrm{a}}\right) & -11\left(3^{\mathrm{a}}, 7^{\mathrm{a}}\right) \\
\text { V } & 11\left(4^{\mathrm{a}} \text { y } 8^{\mathrm{a}} \text { o } 6^{\mathrm{a}}\right) & -11\left(4^{\mathrm{a}} \text { y } 8^{\mathrm{a}} \text { o } 6^{\mathrm{a}}\right) & -9\left(4^{\mathrm{a}}\right) & -10\left(5^{\mathrm{a}}\right)
\end{array}
$$

3. El poeta va acomodando el ritmo en cada caso. Pero es indudable la intención de no renunciar al uso del endecasílabo italiano y, la vez, de desprenderse de un ritmo consabido, rompiendo expectativas y dando lugar a:

a) Combinaciones infrecuentes de metros (endecasílabos, decasílabos, eneasílabos y octosílabos)

b) Disposiciones acentuales no habituales.

En consecuencia, los versos suenan de otro modo, acaso con más lentitud y menos sonoridad.

\section{Otras estrofas de cuatro versos}

Con el análisis de «Poética» hemos entrado en el taller experimental de Bonifaz Nuño. Tras la comprobación de las variaciones y mixturas rítmicas dentro de una misma estrofa, debemos completar el cuadro analizando otros poemas escritos en cuartetos, así como el particular uso que hace el poeta de la estrofa sáfica.

Bonifaz Nuño usa el cuarteto de versos blancos de arte mayor en dos series de poemas: los numerados del 5 al 8 y del 16 al 19, todos ellos en la sección «Imágenes» del libro homónimo.

${ }^{20}$ BAEHR, Rudolf: Manual de versificación española, cit., p. 260. 
A ellos hay que añadir la traducción de una oda de Horacio en la sección «Estudios».

El juego rítmico es distinto en cada serie. En la primera (poemas $5,6,7$ y 8 ), tres poemas constan de cuatro cuartetos y el último de siete. Característica común a las distintas estrofas es la introducción de un verso decasílabo entre los endecasílabos en idéntica posición estrófica en cada poema; por otro lado, todos los versos regularizan el acento en $5^{\text {a }}$ sílaba. Son, por lo tanto, estrofas regulares, como se comprueba en la siguiente tabla:

\begin{tabular}{|c|c|c|c|}
\hline $\begin{array}{c}\text { Poema } \\
\text { n. }\end{array}$ & $\begin{array}{c}\text { Número de } \\
\text { estrofas }\end{array}$ & $\begin{array}{c}\text { Distribución silábica de } \\
\text { cada estrofa }\end{array}$ & Acento constituyente \\
\hline 5 & 4 & $11-11-11-10$ & $5^{\text {a }}$ sílaba \\
6 & 4 & $11-11-11-10$ & $5^{\text {s sílaba }}$ \\
7 & 4 & $11-10-11-11$ & $5^{\text {a sílaba }}$ \\
8 & 7 & $11-11-10-11$ & $5^{\text {a sílaba }}$ \\
\hline
\end{tabular}

La pauta puede observarse en la última estrofa de cada poema:

En el centro oscuro, simple y a ciegas

nuestro corazón camina. Sus pasos

los oye la muerte más claramente

cada vez: más cerca de su puerta. (p. 43)

$* * *$

Pasa, lenta, el agua en sus pies. Espumas

aglomera turbias, esconde flores,

y manos y pájaros muertos lleva

entre lisos lomos y raíces. (p. 44)

$\mathrm{Y}$ seres marinos corren a ciegas

entre las arenas conmovidas

por el agua oscura, que suavemente

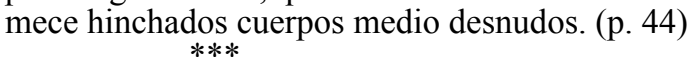

Otra vez la calle, estrecha, los pianos

vistos al través de los vidrios sucios.

$\mathrm{Y}$ blandos rincones, y escaleras

y pequeñas cosas abandonadas. (p. 45) $11\left(3^{\mathrm{a}}, 5^{\mathrm{a}}, 7^{\mathrm{a}}, 10^{\mathrm{a}}\right)$

$11\left(1^{\mathrm{a}}, 5^{\mathrm{a}}, 7^{\mathrm{a}}, 10^{\mathrm{a}}\right)$

$11\left(2^{\mathrm{a}}, 5^{\mathrm{a}}, 7^{\mathrm{a}}, 10^{\mathrm{a}}\right)$

$10\left(1^{\mathrm{a}}, 3^{\mathrm{a}}, 4^{\mathrm{a}}, 5^{\mathrm{a}}, 9^{\mathrm{a}}\right)$

$11\left(1^{\mathrm{a}}, 3^{\mathrm{a}}, 5^{\mathrm{a}}, 8^{\mathrm{a}}, 10^{\mathrm{a}}\right)$

$11\left(3^{\mathrm{a}}, 5^{\mathrm{a}}, 8^{\mathrm{a}}, 10^{\mathrm{a}}\right)$

$11\left(2^{\mathrm{a}}, 5^{\mathrm{a}}, 8^{\mathrm{a}}, 10^{\mathrm{a}}\right)$

$10\left(1^{\mathrm{a}}, 3^{\mathrm{a}}, 5^{\mathrm{a}}, 9^{\mathrm{a}}\right)$

$11\left(2^{\mathrm{a}}, 5^{\mathrm{a}}, 7^{\mathrm{a}}, 10^{\mathrm{a}}\right)$

$10\left(5^{\mathrm{a}}, 9^{\mathrm{a}}\right)$

$11\left(3^{\mathrm{a}}, 5^{\mathrm{a}}, 8^{\mathrm{a}}, 10^{\mathrm{a}}\right)$

$11\left(1^{\mathrm{a}}, 3^{\mathrm{a}}, 5^{\mathrm{a}}, 10^{\mathrm{a}}\right)$

$11\left(1^{\mathrm{a}}, 3^{\mathrm{a}}, 5^{\mathrm{a}}, 7^{\mathrm{a}}, 10^{\mathrm{a}}\right)$

$11\left(1^{\mathrm{a}}, 5^{\mathrm{a}}, 8^{\mathrm{a}}, 10^{\mathrm{a}}\right)$

$10\left(2^{\mathrm{a}}, 5^{\mathrm{a}}, 9^{\mathrm{a}}\right)$

$11\left(3^{\mathrm{a}}, 5^{\mathrm{a}}, 10^{\mathrm{a}}\right)$

La estrofa (cuarteto) y la estructura de la misma, basada en introducir un decasílabo entre los endecasílabos y la acentuación 
regular en $5^{\mathrm{a}}$ sílaba, señalan o marcan los límites a los experimentos rítmicos del poeta mexicano.

En la segunda serie (poemas 16, 17, 18 y 19) las cuatro composiciones constan de cinco estrofas cada una que son cuartetos de versos blancos de arte mayor cuyas características diferenciales con la serie anterior es la no regularización acentual sobre la $5^{\mathrm{a}}$ sílaba y la mezcla de los ritmos tradicionales del endecasílabo con el decasílabo y el eneasílabo, según la siguiente disposición silábica y acentual en la que se aprecia la regularidad establecida por el poeta:

\begin{tabular}{|c|c|c|l|}
\hline $\begin{array}{c}\text { Poema } \\
\text { n. }\end{array}$ & $\begin{array}{c}\text { Número de } \\
\text { estrofas }\end{array}$ & $\begin{array}{c}\text { Distribución } \\
\text { silábica de cada } \\
\text { estrofa }\end{array}$ & \multicolumn{1}{|c|}{ Acento constituyente } \\
\hline 16 & 5 & $11-11-9-10$ & - Endecasílabos en $6^{\mathrm{a}}$ o en $4^{\mathrm{a}} \mathrm{y}$ \\
17 & 5 & $11-11-9-10$ & $8^{\mathrm{a}}$. \\
18 & 5 & $11-11-9-10$ & - Eneasílabos en $4^{\mathrm{a}}$. \\
19 & 5 & $11-11-9-10$ & - Decasílabos en $5^{\mathrm{a}}$. \\
\hline
\end{tabular}

Compruébese la tabla en la primera estrofa de cada poema:

La breve hoja de papel. Despojo.

Fantasma de papel amarillento en que una sombra de palabras

renueva la tinta envejecida. (p. 57)

De la tranquila altura del cabello a la mano de ella, y de su mano al corazón de la nostalgia, la rosa desciende blanda y sola. (p. 58)

Una mano en la nuca, la cabeza de leve lumbre coronada, el cuello, la simple gracia de la espalda surgiendo entre sábanas desnuda. (p. 59)

Era la noche, y en lo alto el cielo, entre menores lumbres y ceniza turbia de nubes, asomada colgaba la esfera de la luna. (p. 59)

$\begin{array}{cl}11 & \left(1^{\mathrm{a}}, 4^{\mathrm{a}}, 8^{\mathrm{a}}, 10^{\mathrm{a}}\right) \\ 11 & \left(4^{\mathrm{a}}, \mathrm{6}^{\mathrm{a}}, 10^{\mathrm{a}}\right) \\ 9 & \left(1^{\mathrm{a}}, 4^{\mathrm{a}}, 8^{\mathrm{a}}\right) \\ 10 & \left(2^{\mathrm{a}}, 5^{\mathrm{a}}, 9^{\mathrm{a}}\right)\end{array}$


De nuevo ha de indicarse que los experimentos rítmicos de Bonifaz Nuño guardan manifiesta regularidad. Esta estructura la sigue el poeta en los siete cuartetos de su traducción de la Oda XIV del Libro II de Horacio: 11 - 11 - 9 - 10, con alguna limitación en la primera estrofa, en la que el primer verso ( $i A y$, ay!, fugaces, Póstumo, Póstumo») para ser endecasílabo necesitaría regularizar el final de verso sobre palabra llana. De igual modo, en esa primera estrofa, el eneasílabo («detendrá las rugas, la instante») acentúa en $3^{\mathrm{a}}$ y $5^{\mathrm{a}}$ (no en $4^{\mathrm{a}}$ ) y el de la estrofa cuarta en $2^{\mathrm{a}}$ y $5^{\text {a }}$ (《en vano en otoño, miedosos»), a diferencia de los demás, que lo hacen en $4^{\mathrm{a}}$. También el decasílabo de la primera estrofa acentúa las sílabas $3^{\mathrm{a}}$ y $7^{\mathrm{a}}$ («senectud, y la indomada muerte»), y el de la segunda en $2^{\mathrm{a}}$ y $6^{\mathrm{a}}$ («y a Ticio con las fúnebres hondas»), a diferencia de los demás, que lo hacen con regularidad en $5^{\text {a }}$ sílaba. Tal vez las dificultades de la traducción hayan provocado tales disfunciones rítmicas, si las comparamos con la regularidad sostenida por el poeta en las series anteriores.

Puede concluirse afirmando que el poeta Rubén Bonifaz Nuño experimenta con las estrofas, con los versos, con el ritmo de los mismos y con la combinación de diferentes ritmos versales en cada estrofa, pero dentro de ciertas regularidades que lo alejan de posibles estridencias; estas regularidades afectan a la estrofa (cuartetos), a los poemas, que tienden a disponer del mismo número de estrofas, a la conformación de cada estrofa dentro de cada poema y a lo largo de la serie en que el poema se enmarca y a la sistematicidad acentual.

La diferencia entre los poemas de la primera serie $(5,6,7$ y 8$)$ y los de la segunda $(16,17,18$ y 19) son:

a) En la primera, las estrofas constan siempre de tres endecasílabos y un decasílabo que regularizan su acento constitutivo en $5^{\mathrm{a}}$ sílaba.

b) En la segunda, los endecasílabos se combinan con decasílabos y eneasílabos, pero con diferente ritmo acentual de los diferentes metros, mezclando la tradición del endecasílabo italiano (heroicos y sáficos) con la del eneasílabo de canción (acento en $4^{\mathrm{a}}$ ) y el decasílabo con acento en $5^{\mathrm{a}}$ que rompe, por lo tanto, las expectativas rítmicas de los otros versos con acentos fijos en sílaba par. 


\section{La estrofa sáfica}

Caso interesante y diferente es el de otro tipo de estrofa de cuatro versos, la estrofa sáfica, también empleada por Bonifaz Nuño. Por definición, dicha estrofa es una combinación de cuatro versos blancos, los tres primeros endecasílabos sáficos (acentuados en $4^{\mathrm{a}}$ y $8^{\mathrm{a}}$ sílabas) y el cuarto, pentasílabo adónico (acentos en $1^{\mathrm{a}}$ y $4^{\mathrm{a}}$ sílabas). A lo largo del tiempo, la estrofa sáfica ha conocido distintos matices rítmicos, prescindiendo del carácter sáfico del endecasílabo o del carácter adónico del pentasílabo o introduciendo formas asonantadas y aconsonantadas ${ }^{21}$. Bonifaz Nuño da un paso más en la reelaboración moderna de la estrofa: en primer lugar, el endecasílabo adquiere la vieja forma del galaico antiguo, con acentuación fija en $5^{\mathrm{a}}$ sílaba y variabilidad acentual en las demás; en segundo lugar, el pentasílabo puede ser o no ser adónico; en tercer lugar, el poeta no acompasa el ritmo de los endecasílabos con el pentasílabo de cada estrofa. En el modelo clásico de Villegas en su oda «Al céfiro», los endecasílabos acentuaban en $1^{\mathrm{a}}, 4^{\mathrm{a}}$ y $8^{\mathrm{a}}$ sílabas, por lo que sus dos primeras sílabas tónicas coincidían posicionalmente con las del adónico. Bonifaz Nuño no guarda tal acompasamiento rítmico, como se comprueba en el esquema acentual de la última estrofa de «El caracol» (ya citado dentro de Algunos poemas no coleccionados, 1945-1952), cuya parte tercera se compone de tres estrofas sáficas:

Sueño que he tenido el mar en mi mano.

$\left(1^{\mathrm{a}}, 5^{\mathrm{a}}, 7^{\mathrm{a}}, 10^{\mathrm{a}}\right)$

En un caracol profundo, en la imagen

$\left(5^{\mathrm{a}}, 7^{\mathrm{a}}, 10^{\mathrm{a}}\right)$

de la gota esbelta que por sus dedos

tiembla y resbala. (p. 37)

$\left(3^{\mathrm{a}}, 5^{\mathrm{a}}, 10^{\mathrm{a}}\right)$

$\left(1^{\mathrm{a}}, 4^{\mathrm{a}}\right)$

El poeta indaga en las formas y ritmos heredados para forzar sutilmente, sin aparente violencia, su armadura, con el fin de conseguir matices rítmicos nuevos, no experimentados con anterioridad, con los cuales el lector hubo y ha de familiarizarse.

${ }^{21}$ Martínez, José Enrique: «La estrofa sáfica y sus variantes en la poesía de Antonio Carvajal», en Antonio Chicharro y Antonio Sánchez Trigueros (eds.): Júbilo del corazón. Homenaje al poeta y profesor Antonio Carvajal. Granada: Universidad, 2013, pp. 109-125. 
«El caracol» está fechado en 1952; el libro Imágenes, segundo del poeta, se publica en 1953, y en él incluye el poeta dos nuevos poemas en estrofas sáficas, los numerados como 3 y como 21. El primero construye un cuadro impresionista en torno a la imagen desvaída de unos caballos, vagas siluetas entre la niebla, «lentamente sonoros». Una niña mira tras la ventana -en un pueblo de vidas pobres, tristes y solas-, ante la que se detiene un jinete. No ocurre nada más. La insinuación, la sugerencia, tal vez la ilusión o la esperanza anidan en el silencio que sigue al poema. He aquí una de las estrofas:
En el aire, un agrio sabor mojado; un ruido en la tierra sordo; un silencio de móviles dientes abajo. El alma se mira sola. (p. 42)

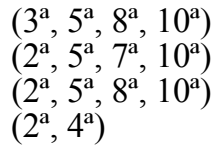

En el segundo de los poemas, el 21, la delicadeza de la tenue figura femenina que dibuja parece signada por la muerte, sin duda destinataria de las palabras del poema, cuya última estrofa evoca el modelo canónico de Villegas, con el contraste temático entre el «vital aliento» que era el céfiro en el poeta de las Eróticas o amatorias (1618) y el calificativo «triste» del mexicano, triste porque el «céfiro blando» es el que anuncia la presencia de la muerte:

Tú que alegres hojas, nubes ligeras, aromas conmueves, en ella sólo pondrás confusión y desorden. Triste céfiro blando. (p. 61)

Podemos extraer algunas conclusiones sobre el uso que hace de la estrofa sáfica Bonifaz Nuño:

1. Los pentasílabos pueden ser o no ser adónicos, pues el acento primero, si lo hay, puede recaer sobre la primera o la segunda sílaba.

2. Los endecasílabos, «galaicos antiguos», van acentuados indefectiblemente en $5^{a}$ sílaba, pudiendo variar el resto de las posiciones acentuales.

3. Los endecasílabos tienden a dividirse en hemistiquios de 
seis y cinco sílabas respectivamente, pero no ocurre así en versos cuyo acento constituyente recae sobre palabra aguda o esdrújula: «en espigas húmedas, / con dulzura», «hay un pueblo pálido, / pululando», «flores, flores húmedas; / lentos pliegues», «pondrás confusión y desorden. Triste».

4. Los viejos moldes métricos han sido forzados sin quiebra aparente para adaptarlos a nuevos ritmos y a una nueva música. El poeta no recurre a extravagancias, sino al uso de formas fijadas por la tradición y que a lo largo de los siglos han ido adaptándose a nuevas necesidades expresivas. La innovación llevada a cabo por Bonifaz Nuño no difiere del conjunto de experimentos rítmicos ensayados por el poeta, principalmente en relación con el endecasílabo y sus posibles combinaciones, si bien no cabe duda de que su intervención transgrede una de las leyes rítmicas acentuales de dicho metro asumidas sin discrepancia por la tradición métrica española.

\section{La silva libre}

La «silva libre», cuya denominación y caracterización se debe a Isabel Paraíso, puede definirse como «poema formado por la combinación de versos de distinta medida, par e impar; no se organiza en estrofas y generalmente prescinde de la rima» ${ }^{22}$.

Páginas atrás aludíamos a la alternancia de silvas y sonetos en el «Canto del afán amoroso» con que concluye Imágenes. Se trata ahora de referirnos en exclusiva a dicho tipo de composición no estrófica. libre:

El poema primero de Imágenes puede entenderse como silva

Cuando duermo -lejos-, cuando la carne no es más que una costra débil de niebla sobre los endebles huesos,

y atrás de los dientes enmudece

contra el paladar la lengua, temblando;

10

11

cuando todo es blando y sin forma, espeso -tal como si el sueño viniera

${ }^{22}$ Domínguez Caparrós, José: Diccionario de métrica española, cit., p. 394. 
por los secretísimos caminos

que ha de recorrer la muerte algún día-,

siento que me llamas, y en tu boca

11

llega la canción que cantaste a oscuras

una vez, delante de mí.

Cantabas.

Y yo que te escucho paso en silencio.

11

Lloro encadenado al sueño triste

10

como al pie del mástil solo de un barco. (p. 41)

La silva libre transcrita es, por lo tanto, la combinación de versos endecasílabos (nueve), decasílabos (cuatro), eneasílabos (uno) y octosílabos (uno). La variabilidad silábica se compensa con la regularidad acentual en $5^{\mathrm{a}}$ sílaba. Dada la predominancia -en esta y en las demás silvas del poeta- del endecasílabo, podría hablarse de «ritmo endecasilábico antiguo», a semejanza del «ritmo endecasilábico» que suele aplicarse en la silva libre más común o en los versos libres que tienden a acentuar la sílaba $6^{\mathrm{a}}$ o la $4^{\mathrm{a}}$ y $8^{\mathrm{a}}$.

Silvas libres son también el poema 10, titulado «Motivos del 2 de noviembre», en cinco partes (64 versos) y 14, «Balada», en cinco partes también (45 versos). La primera silva combina endecasílabos (44), decasílabos (13), eneasílabos (5) y octosílabos (1); a ellos ha de añadirse un tetradecasílabo («y también alegres motivos hay, si del luto») que, como los demás versos acentúa en $5^{\mathrm{a}}$ sílaba (además de en otras sílabas interiores). He aquí un breve fragmento:

$\begin{array}{lll}\text { Jóvenes mujeres suntuosas pasan } & 11 & \left(1^{\mathrm{a}}, 5^{\mathrm{a}}, 8^{\mathrm{a}}, 10^{\mathrm{a}}\right) \\ \text { llevando pesados olores, } & 9 & \left(2^{\mathrm{a}}, 5^{\mathrm{a}}, 8^{\mathrm{a}}\right. \\ \text { y en miradas altas sostenidas } & 10 & \left(3^{\mathrm{a}}, 5^{\mathrm{a}}, 9^{\mathrm{a}}\right) \\ \text { flotan las solemnes nubes. (p. } 47) & 8 & \left(1^{\mathrm{a}}, 5^{\mathrm{a}}, 7^{\mathrm{a}}\right)\end{array}$

También la «Balada» combina versos endecasílabos (29), decasílabos (7), eneasílabos (6) y octosílabos (2). El poema se cierra con un hexasílabo, disponiendo de otro modo dos versos de Quevedo: «Huyó lo que era firme, y solamente / lo fugitivo permanece y dura»: 
$\mathrm{Y}$ a veces recuerdo cosas muy dulces de ti: solamente lo fugitivo permanece y dura. (p. 57)

Al dividir de otro modo los versos quevedescos, el poeta mexicano establece un contraste aún más fuerte en la paradoja de que lo que huye es lo único permanente, al dejar en un verso lo fugitivo y en el otro, cerrando el poema con un asiento bimembre, lo que «permanece y dura».

En cualquier caso, los versos, de una u otra medida, regularizan su ritmo acentual sobre la $5^{\mathrm{a}}$ sílaba, con posiciones variables para los demás acentos interiores. Unas y otras silvas -al igual que los versos en estrofas de cuatro versos- manifiestan un claro predominio del endecasílabo con acento en $5^{\mathrm{a}}$, ritmo acentual al que se acomodan los demás metros.

\section{De Imágenes en adelante}

Desde la publicación de Imágenes en 1953 ya no puede decirse que el uso del endecasílabo galaico antiguo sea excepcional ni falto de ejemplos. En dicha obra y en el resto de su producción, Rubén Bonifaz Nuño no sólo proporciona abundantísimos ejemplos del mencionado metro en composiciones enteras basadas en él, sino de sus posibles combinaciones con metros cercanos también inusuales en cuanto al nuevo y reiterado ritmo acentual. Ha logrado variedades rítmicas sin estridencias, ha hecho cantar al verso español de otro modo, como indicaba Sandro Cohen, pero sin abandonar el uso de los ritmos tradicionales (endecasílabos a la manera italiana) en las formas clásicas (sonetos, liras, silvas, etc.)

En efecto, tras una breve indagación en la abundante producción posterior a Imágenes, puede señalarse que las formas innovadoras indicadas -fundamentalmente la combinación de versos de arte mayor acentuados en $5^{\mathrm{a}}$ sílaba- se instaló definitivamente en el taller poético de Bonifaz Nuño, al tiempo que cultivaba los ritmos y formas clásicos. Los demonios y los días (1956), que sigue cronológicamente a Imágenes, se compone de 42 poemas numerados, sin título. Los versos, sin rima, acentúan todos en $5^{\mathrm{a}}$ sílaba, por lo que la regularidad es esencialmente 
acentual; silábicamente combina, salvo alguna excepción, versos endecasílabos, decasílabos, eneasílabos y octosílabos, según costumbre, como se aprecia en este fragmento del poema 2:

$\begin{array}{ll}\text { Hace falta estar atentos, tendidos } & 11 \\ \text { para no perdernos nada; } & 8 \\ \text { para recobrar lo que olvidamos. } & 10 \\ \text { Pensar, conocer, por ejemplo, } & 9 \\ \text { qué es lo que sucede cuando se encuentran } & 11 \\ \text { dos que van a amarse; qué, cuando muere } & 10 \\ \text { a solas alguno que quisimos. } & 10 \\ \text { Y cuando sentimos que un invisible } & 11 \\ \text { se instala de pronto al lado nuestro, } & 10 \\ \text { o se va en secreto, nos abandona, } & 11 \\ \text { ¿qué hay, que no era nuestro, en la primera } & 10 \\ \text { mirada, el saludo que cambiamos con alguien? (p. 116) } & 13\end{array}$

La acentuación en $5^{\mathrm{a}}$ sílaba no supone el abandono del ritmo endecasilábico tradicional, al que se acogen las silvas libres de El manto y la corona (1958), con versos de distintas medidas, o Fulgor de pobres (1961). En algunos casos, Bonifaz Nuño tiende al uso del ritmo endecasilábico tradicional (con acentos en $6^{\mathrm{a}}$ o $4^{\mathrm{a}}$ y $8^{\mathrm{a}}$ sílabas, sean de la medida que sean) con el ritmo nuevo de acentuación en $5^{\mathrm{a}}$ sílaba (o incluso a veces en $7^{\mathrm{a}}$ ), como en El ala del tigre (1969) o en La flama en el espejo (1971). De El ala del tigre, 85 poemas, cada uno de los cuales se compone de tres sextetos, proceden los siguientes versos, en los que se observa cierta regularidad acentual, que, a falta de un análisis exhaustivo, sugiere que los decasílabos acentúan regularmente en $5^{\mathrm{a}}$ y los eneasílabos -los dos versos combinados a lo largo del libro- son de carácter yámbico:

$\begin{array}{lll}\text { Como una fruta que disuelve } & 9 & \left(4^{\mathrm{a}}, 8^{\mathrm{a}}\right) \\ \text { contra el paladar sus alas dulces, } & 10 & \left(5^{\mathrm{a}}, 7^{\mathrm{a}}, 9^{\mathrm{a}}\right) \\ \text { o como retoños de las uvas, } & 10 & \left(5^{\mathrm{a}}, 9^{\mathrm{a}}\right) \\ \text { la noche del cantar me puebla. } & 9 & \left(2^{\mathrm{a}}, 6^{\mathrm{a}}, 8^{\mathrm{a}}\right) \\ \text { Y tú, serpiente desolada, } & 9 & \left(2^{\mathrm{a}}, 4^{\mathrm{a}}, 8^{\mathrm{a}}\right) \\ \text { con mi corazón te regocijas. (p. 359) } & 10 & \left(5^{\mathrm{a}}, 9^{\mathrm{a}}\right)\end{array}$

Los análisis efectuados bastan para constatar la experiencia innovadora de Rubén Bonifaz Nuño, que llega hasta su último 
libro, Calacas (2003), en el que es fiel a su acentuación en $5^{\text {a }}$ sílaba.

A las novedades rítmicas del poeta mexicano habían aludido ya algunos comentaristas o críticos de su país -aunque falte un análisis pormenorizado de las mismas-, como indican las dos citas que se transcriben a continuación:

Durante años estas variaciones tan sutiles pasaron inadvertidas para la mayoría de los lectores, incluyendo a los críticos, pero el poeta siguió explorando cómo hacer que el verso en español cantara de otro modo. Puede argumentarse que se valió de conceptos rítmicos helénicos y romanos -no en balde ha traducido al castellano gran parte del canon clásico-, o que se sirvió de sus estudios de poesía mexica, cuyas resonancias se escuchan claramente a lo largo de casi toda su obra. También es innegable la influencia de la poesía popular en Rubén Bonifaz Nuño, la cual llega por medio de la canción ranchera, el corrido o el son veracruzano. Sea como fuere, la versificación del poeta es compleja, rica en tonalidades e insinuaciones sonoras que juegan sabia y casi imperceptiblemente con los fondos pero el resultado es una voz inconfundible, única ${ }^{23}$.

La segunda cita incide en lo que de revolución y ruptura pueden tener las innovaciones rítmicas de Bonifaz Nuño:

La revolución métrica de Bonifaz Nuño, y estoy seguro de que hay que denominarla así, consiste en introducir entre nosotros un verso peculiar que parece no obedecer a ninguna medida pero que de modo invariable exhibe un acento constitutivo en la quinta sílaba. Esta acentuación enteramente anómala en la quinta, que él convierte en procedimiento, o sea, en fórmula operativa, tiene por objeto romper la música automatizada del endecasílabo, que es el metro que ha dominado en la poesía culta de nuestra lengua desde los tiempos de los Siglos de Oro. Que ha dominado, incluso, así sea como trasfondo o como modelo críptico, mantenido en lo oscuro, en gran parte de lo que entre nosotros se reconoce como verso libre. La aportación de Bonifaz Nuño, entonces, es realmente trastornadora. Impone una ruptura, una dicción desconocida al mismo tiempo que extrañamente familiar ${ }^{24}$.

${ }^{23}$ CoHEn, Sandro: «El universo poético de Rubén Bonifaz Nuño», en BonIFAz NuÑo, Rubén: Luz que regresa. Antología, cit. p. 9.

${ }^{24}$ Escalante, Evodio: «El destinatario desconocido. La poesía de Rubén Bonifaz Nuño». Círculo de Poesía. Revista electrónica de poesía, enero 2013, 31. http:// circulodepoesia.com/nueva/2013/01/el-destinatario-desconocido-la-poesia-deruben-bonifaz-nuno-por-evodio-escalante (consulta: 8 de marzo de 2013). 
Las destrezas rítmicas de Bonifaz Nuño, su búsqueda continua de novedades dentro de los versos de la tradición, tanto en cada uno de ellos en concreto como en sus combinaciones, merecen un análisis de mayor calado que se ocupe de cada libro en particular y del conjunto de su obra. Aquí se ha pretendido únicamente desbrozar los primeros pasos del camino. 